\title{
抑うつ予防を目的とした自助ツールとしてのコンピュータ ゲームに対する大学生の評価
}

\author{
宮野 秀市 \\ 宮崎大学安全衛生保健センター７889-2192 宮崎県宮崎市学園木花台西1-1 \\ E-mail: miyano@med.miyazaki-u.ac.jp
}

\begin{abstract}
概要 本研究の目的は、抑うつ予防を目的とした自助ツールとしてのコンピュータロールプレイング ゲームに対する大学生の評価を明らかにすることである。認知行動療法の理論にもとづいて作成された、 ワークブック、ウェブサイト、ボードゲーム、コンピュータロールプレイングゲームの四つの自助ツー ルについての評価を比較検討した。その結果、コンピュータロールプレイングゲームは、他の自助ツー ルよりも大学生に好まれることがわかった。さらに、各自助ツールに対する自由記述の評価文のテキス トマイニングによって、コンピュータロールプレイングゲームは「楽しい」「面白い」「「やってみたい」 などの肯定的な評価をされることがわかった。本研究の結果から、コンピュータロールプレイングゲー ムの形式で作成された抑うつ予防を目的とした自助ツールは、ユーザーに利用されやすいことが示唆さ れた。

キーワード 抑うつ、認知行動療法、自助、コンピュータゲーム、テキストマイニング
\end{abstract}

\section{1. 問題と目的}

認知行動療法は、ものごとに対する考え方や受け取 り方が気分や行動に影響していることに注目し、柔軟 な考えができるように援助することで不適応状態を 改善しようとする心理療法である ${ }^{[1]}$ 。認知行動療法は うつ病の治療に有効であることが認められており ${ }^{[2][3] 、 ~}$ コンピュータの普及にともない、うつ病の予防や治療 を目的とした認知行動療法にもとづくコンピュータ プログラムも開発されている。

そうしたプログラムには、例えば、「Beating the

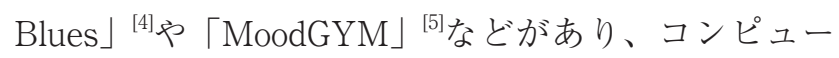
タにインストールするか、あるいはインターネットを 介したウェブサイト上のプログラムとして用いられ、 うつ病の予防や改善に効果があることが示されてい $る^{[6][7]}$ 。う病の予防や改善を目的としたコンピュー 夕を利用する従来の自助プログラムを概観すると、そ れらはテキストやイラスト、アニメーション、ビデオ 映像や音声などで構成されているが、実質的には自助 のためのワークブックをパーソナルコンピュータの モニター上に再現したものであるといえる。つまり、 モニターに表示されるテキストを読んだりプログラ
ムの指示に従って指定された空闌へキーボードからテ キストを入力することによって学習を進める仕組みに なっている。しかしながら、そのような学習方法はテ キスト入力が面倒くさく尔、押しつけがましいと感じ るユーザーもいる ${ }^{[9110]}$ 。そのため、これらのコンピュー タプログラムはユーザーからはあまり好まれず、利用 される割合は $3.3 \%$ 25\%と低く、ドロップアウト率 も30\%以上と高いことが問題となっている ${ }^{[11]}$ 。

ところで近年、心身の健康の維持や増進などのへル スケアを目的としたコンピュータゲームの研究が進ん

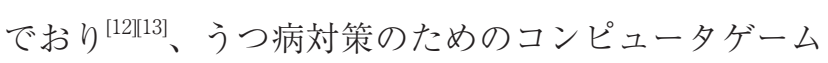
も開発されている。例えば、SPARX ${ }^{[14]}$ やReach Out Central ${ }^{[15]}$ は認知行動療法の理論にもとづいたコン ピュータゲームであり、うつ状態や心理的苦痛の低減 に効果があることが示されている。学習とコンピュー タゲームを組み合わせることは、ユーザーをより没頭

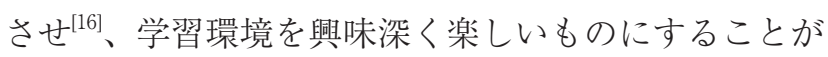

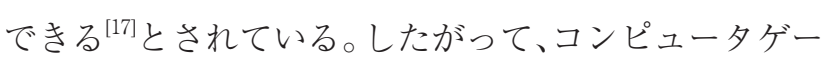
ムの形式をとった自助ツールは、ユーザーから好まれ、 利用率も高くなることが期待される。

本研究の目的は、ワークブックやワークブック形式 
の従来のコンピュータプログラムなどの自助ツールと 比較して、コンピュータゲームの形式をとる自助ツー ルがユーザーからどれほど好まれるかを調査し、さら に、どのように評価されるかをテキストマイニングの 手法を用いて明らかにすることである。

\section{2. 調查 1 と 2 で使用した自助ツール}

\section{1 自助ツールの呈示方法}

認知行動療法の理論にもとついて、偏った考え方を 変えることで感情や行動の不適応を変容させることを 目的に作成された以下の四つの自助ツールの概要や使 用方法をプレゼンテーションソフトとプロジェクタを 用いて、それぞれについて $3 \sim 4$ 分程度説明した。

\subsection{1 ワークブック:「うつと不安の認知療法練習帳」[18]}

日常的な出来事に対する誤った解釈や極端な信念な どの考え方がうつ状態を引き起こしていることを学 び、そうした考え方を変えることを目的とした標準的 なワークブックである。うつ状態を引き起こす自分の 非適応的な考元方やそれに替わる適応的な考え方を紙 に書き出すなどの作業が求められる。

\subsection{2 ウェブサイト:「MoodGYM」<1>}

ワークブックと同様なことをウェブサイト上ででき るようにしたコンピュータプログラムであり、非適応 的な考え方や適応的な考え方をキーボードを用いて直 接ウェブページへ入力する。ただ、考え方が感情や 行動に影響することの学習や、自分の偏った考え方の 確認がサイト上のボタンや登場人物などをクリックす ることでインタラクティブに行える仕組みがある。

\subsection{3 ボードゲーム : 「Let's get Rational New}

\section{Edition」<2>}

認知行動療法の一種である論理療法にもとづいてグ ループカウンセリングで使用することを目的に開発さ れた、複数人でプレイするボードゲームである ${ }^{[19]}$ 。プ レイヤーはサイコロを振ってボード上の自分のコマを 進め、止まったマス目に書かれている指示に従う。例 えば、適応的で合理的な考え方が書かれたカードの束 から 1 枚引いてそのカードの文章の意味を他のプレイ ヤーに説明する、あるいはロールプレイをするなどし て合理的な考え方や適切な振る舞い方を身に付ける。

\subsection{4 コンピュータRPG : 「Rational Quest」}

コンピュータRPG形式の自助ツールの概要を説明す るために「RPGツクールVX Ace」く3>を用いて著者が 作成したもの。主人公である学生には、不本意入学、 進路や進学、友人との人間関係など、大学生が直面す ることが多いと思われる困難な問題が起こる。プレイ ヤーは主人公を操作し、他のキャラクターからアドバ イスを受けながらそれらの問題を解決していくこと で、遊びながら認知行動療法を学習できる。主人公が 街中を移動して出会ったキャラクターと会話する様子 や、認知行動療法を教授するキャラクターと会話し、 学習の理解を確認するために出題される 4 択問題に回 答する様子などを収録したデモ動画を呈示した。

\section{3. 調查 1 ：各自助ツールの好まれやすさ 3.1 調查方法}

大学での心理療法の講義中に上記の四つの自助ツー ルを呈示し、それぞれどの程度やってみたいかにつ いて、0 点〜 10点の範囲で回答を求めた。ただし、 $\lceil$ MoodGYM」と「Let's get Rational New Edition」は 英語のツールのため、四つの自助ツールが「日本語だっ たら、どの程度やってみたいと思うか」と教示した。 調査の際には回答は任意であることや成績評価には一 切影響しないことを告知した。

157名に調査への協力を依頼し、132名から回答を 得た。回答に不備があった者を除き、124名分（男性 112 名、女性 12 名、平均 19 歳 0 力月、18歳 2 力月～ 20 歳10力月）を解析対象とした。

\section{2 結果}

各自助ツールの得点の平均值は、男性では、ワーク

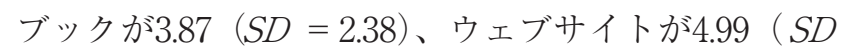

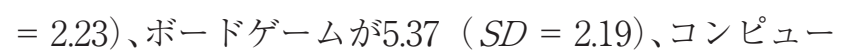
夕RPGが8.09（ $S D=2.33 ）$ であった。女性では、ワー

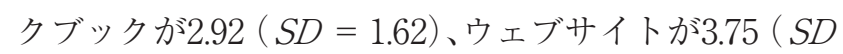

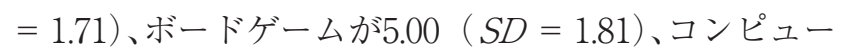
タRPGが7.75（ $S D=1.60 ）$ であった。

各自助ツールの得点の違いについてWilcoxonの符 号付順位検定を性別ごとに行い、Bonferroni法によ 
$\eta p$ 值を調整した。その結果、男性では、コンピュー 夕RPGが、ワークブック $(Z=-7.92, p<.01) 、 ウ ェ ~$

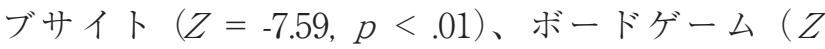
$=-7.50, p<.01 ）$ よりも得点が有意に高かった。ま た、ワークブックは、ウェブサイト $(Z=-4.64, p<$

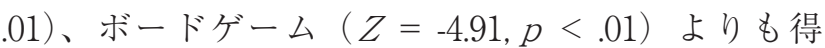
点が有意に低かった。女性においても、コンピュー

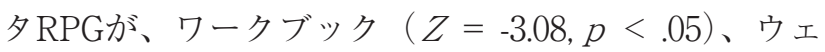

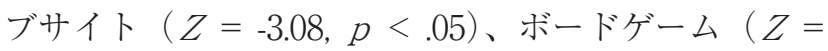
-2.83, $p<.05 ） よ り も$ 得点が有意に高かった。以上の ことから、コンピュータRPGは男性からも女性からも 他の自助ツールょり「やってみたい」と評価されたこ とがわかった。

\section{4. 調查 2 : 各自助ツールの評価文の分析 4.1 調查方法}

大学での心理療法の講義中に上記の四つの自助ツー ルを呈示し、それぞれの教材についてどのような感想 を持ったかについて自由記述で回答を求めた。ただ し、それぞれの文章の最初に「ワークブックは、」、 「インターネットは、」「ボードゲームは、」、「コン ピュータRPGは、」と書き、その後に続けて自由に記 述するように指定した。また、調査 2 では、教材が英 語であることがどのように評価されるかを含めて調查 するため、「MoodGYM」と「Let's get Rational New Edition」について、調査 1 でしたような特別な教示 はしなかった。調査の際には回答は任意であることや 成績評価には一切影響しないことを告知した。

259名に調查への協力を依頼し、167名から回答を得 た。回答に不備があった者を除いた160名分(男性82名、 女性78名。平均19歳 5 力月、18歳 7 力月～24歳 3 力月) のテキストデータを分析対象とした。

\section{2 結果}

\subsection{1 テキストデータからの語の抽出}

テキストマイニングによるテキストデータの分析に は、計量テキスト分析ソフトであるKH Coder ${ }^{[20]}$ (ver. 2.beta.30b) を用いた。計量テキスト分析とは、質的デー 夕にある種の数值化操作を加えることで実現される、
客観的でデー夕探索的なテキストデー夕の分析手法で ある ${ }^{[21]}$ 。テキストデータの中から語を抽出する際には、 漢字とひらがなを統一する、同意語を統一する（例え ば、「若い人」と「若者」)、などのテキストデータの 加工、および、自助ツールの評価語であることを考慮 して、一続きの語として認識させることが適切である と思われる強制抽出語の指定（例えば、「心理療法」、 「ゲーム感覚」、「やってみたい」など）といった前処 理を行い、その後、品詞分析を行った。その結果、以 降の分析のもとになる1455種類の語を抽出した。

\subsection{2 各自助ツールに多くみられた特徴語}

各自助ツールごとに、共起関係が強い上位 20 語を表 1 に示す。コンピュータRPGは「面白い」「楽しい」、 「やってみたい」「一番」という語が多く使われている。 テキストデータをみると、「普通に一番好き。面白そう。 やってて楽しそう。やってみたい」「楽しみながら学 ベるし、やってみたい」というような、面白い・楽し いからやってみたいという評価が多かった。

ボードゲームもまた「楽しい」という語が多く使わ れているが、「人」、他人」、「一人」といった人に関 わる語が多いという特徵があった。これは、ボードゲー ムが複数のプレイヤーで利用するものであることに由 来していると考えられる。テキストデータを見ると、 「一人ではなく多数の人とできるので、楽しく、気軽 に取り組むことができる」、「他人と話をすることがあ るので、話すことが苦手な人には良くない」など、複 数で取り組むことを好意的に評価する者とそうでない 者がいたことがわかる。

ワークブックには、「自分」「書く」、「考え方」「状 況」「気分」といった語が多くみられた。これは、日 常生活で起こる出来事などの状況をどのように考える かによって気分も変わるという認知行動療法のモデル にしたがって、自分の考え方を書くことによって客観 的に理解し、変容をはかるというワークブックの特徵 をよく表していると思われる。また、そのような作業 を「文字にすることで自分を見直せるが、手書きとあ り少し面倒くさい一面があると思う」、「書くという作 業があるので面倒くさく、すすんでやろうという気に ならない」というように面倒くさいと評価する者も多 
表 1 各自助ツールの特徵語

\begin{tabular}{|c|c|c|c|c|c|c|c|}
\hline \multicolumn{2}{|c|}{ work book } & \multicolumn{2}{|l|}{ website } & \multicolumn{2}{|l|}{ board game } & \multicolumn{2}{|c|}{ computer RPG } \\
\hline 自分 & .387 & ワークブック & .182 & 人 & .196 & ゲーム & .278 \\
\hline 書く & .282 & 良い & .171 & 良い & .193 & 面白い & .276 \\
\hline 思う & .250 & クリック & .155 & 楽しい & .180 & 思う & .245 \\
\hline 考え方 & 249 & 手軽 & 137 & 他人 & 157 & やってみたい & .176 \\
\hline 状況 & .169 & 英語 & .098 & 一人 & .131 & 一番 & .162 \\
\hline 本 & .167 & 簡単 & .095 & ゲーム & .122 & 楽しい & .146 \\
\hline 書き込む & .155 & ネガティブ & .085 & 複数人 & .119 & 楽しむ & .100 \\
\hline 気分 & .152 & 感じる & .083 & 楽しむ & .100 & R P G & .088 \\
\hline 良い & .151 & 気軽 & .080 & ゲーム感覚 & .088 & 見る & .075 \\
\hline 考える & .132 & インターネット & .077 & 考え & .083 & 進める & .065 \\
\hline 読む & .107 & ネット & .075 & 考える & .075 & ゲーム感覚 & .063 \\
\hline 理解 & .098 & パソコン & .068 & コミュニケーション & .069 & 若者 & .062 \\
\hline 客観 & .097 & 出る & .066 & 話す & .068 & 世界 & .056 \\
\hline 面倒くさい & .093 & 本 & .063 & 終わる & .068 & 現実 & .056 \\
\hline 整理 & .086 & 結果 & .062 & 一緒 & .061 & 興味 & .054 \\
\hline 感じる & .083 & 便利 & .061 & 友達 & .056 & 好き & .054 \\
\hline 見る & .080 & 読む & .059 & 気軽 & .056 & 論理療法 & .053 \\
\hline 方法 & .079 & 形式 & .056 & 遊ぶ & .056 & やりやす & .052 \\
\hline 文字 & .074 & 出来る & .051 & 意見 & .055 & 主人公 & .050 \\
\hline 少し & .071 & 日本語 & .050 & 楽しめる & .042 & ボードゲーム & .049 \\
\hline
\end{tabular}

かった。

ウェブサイトには、「ワークブック」という語が多 くみられた。これは、テキスト入力という作業がある ことは同じであるが、ワークブックと比較して手軽・ 気軽であるという評価が多かったためである。ワーク ブックと違って、画面上の登場人物や選択肢などをク リックすることで学習を進めていくという要素があ り、それが良い評価を受けていた。ネガティブという 語がみられるのは、この自助ツールにはネガティブな 思考をする悪い例として登場するキャラクターがお り、そのことに言及した評価があったためである。ま た、ウェブサイトは全てが英語表記であるため、評価 文にも「英語なので難しそう」、「英語なので理解する のが大変そうだ」というように英語表記であることに 対する否定的な評価が14件あった。一方、同じく全て が英語表記であるボードゲームにはそのような評価は 2 件しかなかった。

\subsection{3 各自助ツールと特徵語との関係}

次に、各自助ツールと語の関係を視覚的に表現する ために、コレスポンデス分析を行い、寄与率の高い二 つの成分を軸とする 2 次元上へ各自助ツールと語をプ ロットした散布図を作成した（図 1)。あまりに多く の語を配置すると語どうしの関係や語と自助ツールと の関係がわかりにくくなるため、語の最小出現数 15 回 以上とし、さらに、散布図の原点付近に配置される特 徵のない語を除いた上位50語を配置するなどの調整を 行った。成分 1 の固有值は0.302、成分 2 の固有值が 0.173であり、二つの成分までの累積寄与率は $81.17 \%$ であった。

図 1 をみると、コンピュータRPGとボードゲームは 近い関係にあり、その二つとワークブック、ウェブサ イトはそれぞれ遠い関係にあることがわかる。成分 1 は、左方向に「面白い」、「楽しむ」、「ゲーム感覚」、 右方向に「書き込む」、「整理」「客観」が配置されて 


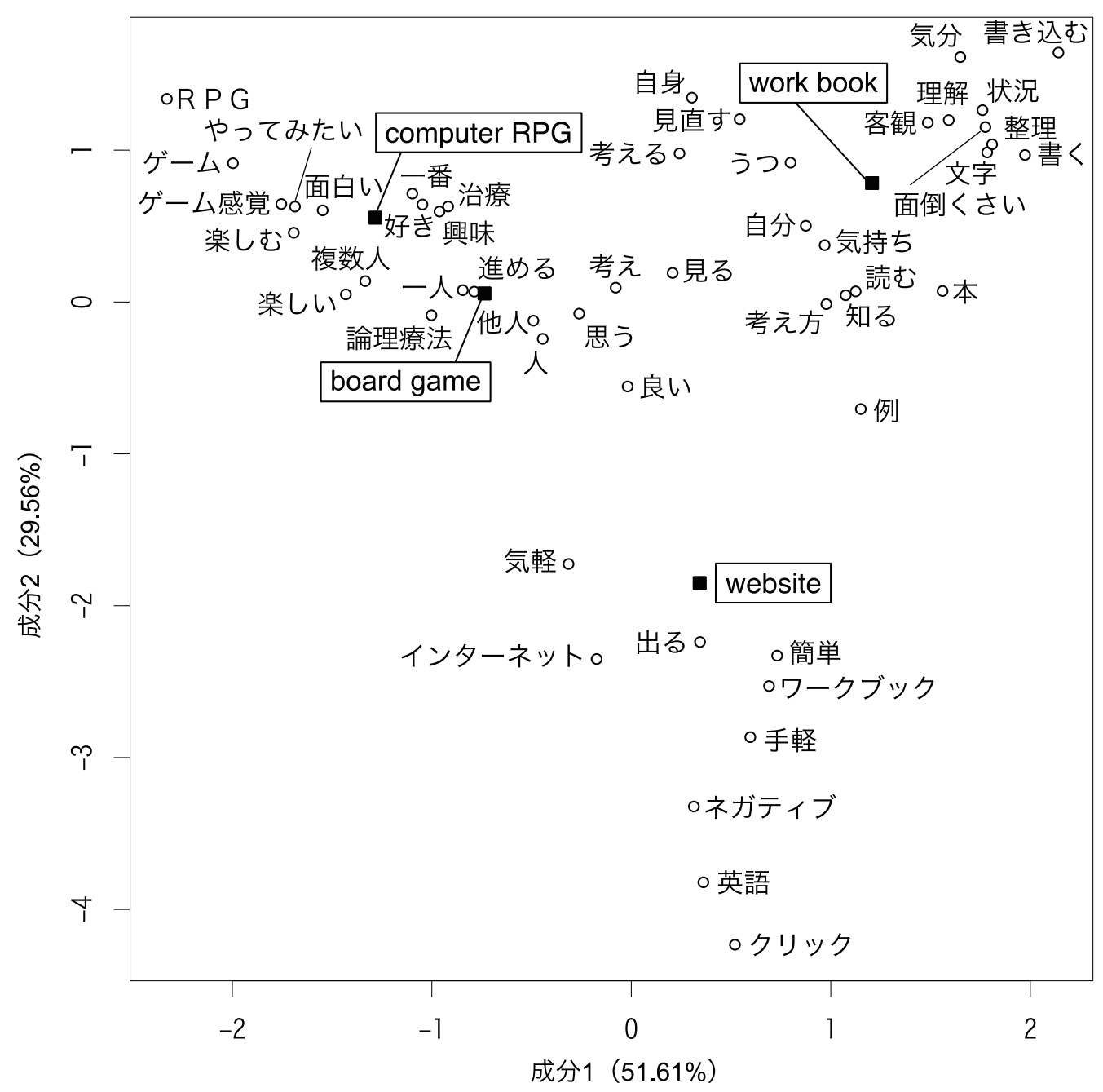

図 1 各自助ツールと特徴語の散布図

おり、“面白い一堅い”が表現されている次元と解䣋 される。成分 2 は、上方向に大きく離れて配置されて いる語はみあたらないが、下方向には「クリック」「英 語」「辛ガティブ」があり、これらが成分 2 の特徵的 な語である。また、ウェブサイトは、原点より下方向 に大きく離れて配置されているが、他の自助ツールは 成分 2 の上方向の狭い範囲に配置されている。これら のことより、成分 2 にはウェブサイトに対する評価で あるか否かが強く影響していると考えられる。

\subsection{4 コンピュータRPGを特徵づける語と語の関係}

次に、コンピュータRPGの特徵語どうしの関係を明 らかにするために、特徵語の共起分析を行った。コン ピュータRPGの評価文に特徵的な上位 60 語までを用 い、次いで、共起の程度が強い上位47の共起関係まで を検討するなど、共起関係をわかりやすくするために
語と共起の数の調整を行い、共起ネットワークを作成 した。共起の程度が強い語どうしは同じ文章中に使わ れることが多い語であることを意味する。

その結果、「一番」と「4つ」、「やってみたい」、「楽 しい」、「興味」に共起が認められた。コンピュータ RPGが他の自助ツールよりもやってみたいと評価され たことが、この共起関係からも伺える。また、自助ツー ルをやってみたいと思わせるには、面白く興味を引く という要素が重要であることが推察される。

「現実」「「世界」「違い」、「多い」には、その四つ の語間だけの共起関係が認められた。テキストデータ を検討すると、「二次元の世界と現実の世界は違うの で、ゲームでうまくいっても現実でうまくいかないこ とが多いのでその違いに落胆しそうだ」、現実の世界 では何の役にも立たないような気がする」など、自助 
ツールとしてのコンピュータRPGに対する不信感が表 現された評価がみられた。そこで、他の三つの自助 ツールを含めたすべての評価文について、「現実」と いう語がどのように使われているか調べたところ、自 助ツールは現実と違うので役に立たないという趣旨の 評価は、コンピュータRPG以外にはみられなかった。

\section{5. 考察}

調査 1 の結果から、コンピュータゲームを利用した 自助ツールは、ワークブックやワークブック形式のコ ンピュータプログラムなどの従来の自助ツールよりも 大学生に「やってみたい」と評価されることがわかっ た。ウェブサイト（ワークブック形式のコンピュータ プログラム）とワークブックの「やってみたい」得点 を比較すると、男性においてはその二つの間に統計的 な有意差はあったものの、男女とも、得点差は10点満 点で 1 点程度であり、それほど大きな差があったわけ ではない。つまり、ワークブックをコンピュータ上に 再現した従来の自助ツールは、ワークブックと同程度 にしか好まれないと言えよう。 Mitchell \& Gordon ${ }^{[22]}$ は、大学生を対象として、うつ状態になったときにカ ウンセリング、インターネットを利用した情報検索、 コンピュータプログラム、ワークブックに対して、 それぞれ利用する可能性がどの程度であると思うか を調査した。その報告によると、カウンセリングは 61.8\%、インターネット検索は60.9\%、コンピュータ プログラムは47.6\%、ワークブックは $43.0 \%$ であった。 調査方法やコンピュータプログラムの内容の違いなど があるため単純に比較することはできないが、ワーク ブックとワークブック形式のコンピュータプログラム の好まれやすさについて大きな差がないという点にお いては、本研究の結果はMitchell \& Gordonの報告と おおむね一致している。

調査 2 の結果から、コンピュータRPGは「面白い」、 「楽しい」などの評価をされることがわかった。中学 校の宇宙科学の授業でコンピュータゲームを学習ツー ルとして利用した研究によると、コンピュータゲーム に対する自由記述の評価文の中に最も多く使われてい た語は"fun"であった ${ }^{[23]}$ 。本研究の結果からも明らかな
ように、コンピュータゲームは学習のツールとしても ユーザーから楽しいと評価されるようである。楽しく 遊びながら学べる学習環境は、学習体験をポジティ ブなものにして学習の成果を高めることができる ${ }^{[23]}$ め、望ましいことと考えられる。しかしながら、ツー ルとしてのゲームが楽しいだけでは、学習者は遊ぶこ とだけに夢中になってしまい、学習そのものをおろそ かにしかねない朔[25]。したがって、ユーザーを楽しま せながら学習に導くようなバランスのよいゲーム要素 の配置が重要であると考えられる。

コンピュータRPGは楽しい、面白いと評価される一 方、現実の世界とは違うので役に立たないという趣旨 の評価もみられた。しかしながら、現実の世界と違う という点においては、コンピュータ RPGも他の自助 ツールも同じである。それにもかかわらず、現実と違 うから役に立たないという趣旨の評価はコンピュータ RPGに対してのみなされた点は興味深い。参加者の中 には、コンピュータゲームというメディアに対して、 ゲームは遊びのためにあるものであり現実の問題解決 の役に立つはずはない、というような考えをもつた者 もいたと推察される。このことは本研究に限らず、シ リアスゲーム導入の際の共通の障害となると思われる。 ウェブサイトとボードゲームはすべてが英語表記で あったが、そのために実行することが難しいという評 価はウェブサイトだけにみられた。カードやボード盤 上のマス目に記述されるような短い英文は苦にならな いが、長文を読むことは自助ツールの使用の妨げにな るようである。海外で効果の検証が行われているよう な自助ツールでも、日本に導入する際には、表記され ている英文と想定されるユーザーの語学力を勘案して 翻訳の検討が必要になることが示唆された。

先に述べたように、コンピュータを利用する従来の 自助プログラムは、プログラムの指示に従って指定さ れた空欄へキーボードからテキストを入力することに よって学習を進める仕組みになっているため、そのよ うな作業が面倒くさく煩雑であると評価されることが あった。しかしながら、本研究においては、ワークブッ クに対する「面倒くさい」という評価が15件あった一 方、ウェブサイトに対する「面倒くさい」という評価 
は 1 件のみであった。この理由としては、四つの自助 ツールが比較された本研究ではウェブサイトがワーク ブックに対して相対的に評価されたことが考えられ る。ワークブックは書き込むことが面倒くさいと評価 された一方、ウェブサイトはクリックすることが手軽 であると評価された。

\section{6. まとめと今後の課題}

本研究の結果から、コンピュータRPGを利用した自 助ツールは、ワークブックやワークブック形式のコン ピュータプログラムなどの従来の自助ツールよりも大 学生に「やってみたい」と評価されること、また、「面 白い・楽しい」と評価されることが明らかになった。 したがって、自助ツールをコンピュータRPGの形式で 作成することには、ワークブックやワークブック形式 のコンピュータプログラムなどの従来の自助ツールに 比ベて、ユーザーの利用率を高めるという意義がある と考えられる。例えば、抑うつ予防を目的としたコン ピュータRPGを作成して大学生に提供すれば、多くの 学生が利用することで抑うつの予防的介入に寄与する ことが期待される。本研究は各自助ツールについて概 要や使い方を数分間呈示した上での評価を求めたもの であり、評価者は実際にツールを使ったわけではない。 しかしながら、その評価状況は、学習者が自助ツール を使うか否かを判断する際の状況には則していたと考 えられる。

今後の課題としては、参加者に実際のコンピュータ RPGをプレイしてもらい、プレイ後の評価や、ドロッ プアウト率などの精査をすることがあげられる。また、 ゲームのプレイが抑うつ予防のための心理教育の学習 や、実際の抑うつの予防や低減に効果があるかどうか の検討も必要である。本研究ではロールプレイング ゲームに対しての評価であった。しかしながら、ユー ザーの評価はコンピュータゲームのジャンルによって も変わることが考えられる。学習ツールとしてのゲー ムを開発する際には、ユーザーとして想定される学習 者の嗜好や学習すべきコンテンツなどを考慮しなが ら、最適なゲームシステムを構築することが必要であ り、今後はそのような研究も求められよう。

\section{謝 辞}

本研究はJSPS科研費 23653204の助成を受けて実施 された。

\section{文 献}

[1] 日本心身医学会（編）（1999）。心身医学用語事典 医学書院

[2] 慶應義塾大学認知行動療法研究会 (編) 厚生労働 科学研究費補助金こころの健康科学研究事業「精 神療法の実施方法と有効性に関する研究」：う つ病の認知療法・認知行動療法治療者用マニュ アル 厚生労働省マニュアル・ガイドライン $<$ 医 師・医療従事者向け $><$ http://www.mhlw.go.jp/ kokoro/speciality/manual1.html>(2013年12月1日)

[3] National Institute for Health and Clinical Excellence (2009) Depression in adults: The treatment and management of depression in adults. National Institute for Health and Care Excellence CG90 Depression in adults: NICE guidance <http://guidance.nice.org.uk/CG90/ NICEGuidance/pdf/English> (2013年12月 1 日)

[4] Proudfoot, J., Goldberg, D., Mann, A., Everitt, B., Marks, I., \& Gray, J. A. (2003). Computerized, interactive, multimedia cognitive-behavioural program for anxiety and depression in general practice. Psychological Medicine, 33(2), 217-227.

[5] Christensen, H., Griffiths, K. M., \& Jorm, A. F. (2004). Delivering interventions for depression by using the Internet: Randomised controlled trial. BMJ, 328:265. doi:10.1136/bmj.37945.566632.EE

[6] Andersson, G., \& Cuijpers, P. (2009). Internetbased and other computerized psychological treatments for adult depression: A meta-analysis. Cognitive Behaviour Therapy, 38(4), 196-205.

[7] Foroushani, P. S., Schneider, J., \& Assareh, N. (2011). Meta-review of the effectiveness of computerised CBT in treating depression. BMC Psychiatry, 11:131. doi:10.1186/1471-244X-11-131

[8] Gerhards, S. A. H., Abma, T. A., Arntz, A., de 
Graaf, L. E., Evers, S. M. A. A., Huibers, M. J. H., \& Widdershoven, G. A. M. (2011). Improving adherence and effectiveness of computerised cognitive behavioural therapy without support for depression: A qualitative study on patient experiences. Journal of Affective Disorders, 129(1-3), 117-125.

[9] Andersson, G., Bergström, J., Holländare, F., Carlbring, P., Kaldo, V., \& Ekselius, L. (2005). Internet-based self-help for depression: Randomised controlled trial. The British Journal of Psychiatry, 187(5), 456-461.

[10] Waller, R., \& Gilbody, S. (2009). Barriers to the uptake of computerized cognitive behavioural therapy: A systematic review of the quantitative and qualitative evidence. Psychological Medicine, 39(5), 705-712.

[11] Kaltenthaler, E., Sutcliffe, P., Parry, G., Beverley, C., Rees, A., \& Ferriter, M. (2008). The acceptability to patients of computerized cognitive behaviour therapy for depression: A systematic review. Psychological Medicine, 38(11), 1521-1530.

[12] Bartolome, N. A., Zorrilla, A. M., \& Zapirain, B. G. (2011). Can game-based therapies be trusted? Is game-based education effective? A systematic review of the serious games for health and education. (pp. 275-282). Presented at the Serious Games (CGAMES), IEEE. doi:10.1109/ CGAMES.2011.6000353

[13] Papastergiou, M. (2009). Exploring the potential of computer and video games for health and physical education: A literature review. Computers \& Education, 53(3), 603-622.

[14] Merry, S. N., Stasiak, K., Shepherd, M., Frampton, C., Fleming, T., \& Lucassen, M. F. G. (2012). The effectiveness of SPARX, a computerised self help intervention for adolescents seeking help for depression: Randomised controlled non-inferiority trial. BMJ, 344:e2598. doi:10.1136/bmj.e2598

[15] Burns, J. M., Webb, M., Durkin, L. A., \& Hickie, I. B. (2010). Reach Out Central: A serious game designed to engage young men to improve mental health and wellbeing. The Medical journal of Australia, 192(11 Suppl), S27-30.

[16] Prensky, M. (2007). Digital game-based learning. St. Paul: Paragon House.

[17] Malone, T. W. \& Lepper, M. R. (1987). Making learning fun: A taxonomy of intrinsic motivations for learning. In R. E. Snow \& M. J. Farr (Eds.), Aptitude, learning and instruction Vol. 3: Conative and affective process analyses. Hillsdale: Lawrence Erlbaum Associates. pp. 223-253.

[18] Greenberger, D., \& Padesky, C. A. (1995). Mind over mood: Change how you feel by changing the way you think. New York: The Guilford Press.(グ リーンバーガー, D. \& パデスキー, C. A. 大野裕(監 訳) (2001). うつと不安の認知療法練習帳 創元社)

[19] Wilde, J. (1994). The effects of the Let's Get Rational board game on rational thinking, depression, and self-acceptance in adolescents. Journal of Rational-Emotive and CognitiveBehavior Therapy, 12(3), 189-196.

[20] 樋口耕一 (2004). テキスト型データの計量的分 析一 2 つのアプローチの峻別と統合一. 理論と方 法, 19(1), 101-115.

[21] 樋口耕一 (2013). KH Coder 2.x チュートリアル (2013年10月 5 日) < http://khc.sourceforge.net/dl.html (Windows版パッケージに同梱) > (2013年12月 7 日)

[22] Mitchell, N., \& Gordon, P. K. (2007). Attitudes towards computerized CBT for depression amongst a student population. Behavioural and Cognitive Psychotherapy, 35(4), 421-430.

[23] Liu, M., Horton, L., Olmanson, J., \& Toprac, P. (2011). A study of learning and motivation in a new media enriched environment for middle school science. Educational Technology Research and Development, 59(2), 249-265. 
[24] Egenfeldt-Nielsen, S. (2006). Overview of research on the educational use of video games. Nordic Journal of Digital Literacy, 1(3), 184-213.

[25] Lim, C. P., Nonis, D., \& Hedberg, J. (2006). Gaming in a 3D multiuser virtual environment: Engaging students in science lessons. British Journal of Educational Technology, 37(2), 211-231.

\section{その他}

$<1>$ MoodGYM (Mark III) (Australian National University) < https://moodgym.anu.edu.au/ welcome> (2012年6月8日)

$<2>$ Let's get Rational New Edition, Wilde, J., LGR Publishing, 1990

$<3>$ RPGツクールVX Ace, ENTERBRAIN, 角川ゲーム ス, 2011. (PC)

\title{
University students' evaluation of a digital game as a self-help tool to prevent depression
}

\author{
Hideichi MIYANO \\ Health Care and Security Center, University of Miyazaki 1-1, Gakuen Kibanadai-nishi, Miyazaki-shi, \\ 889-2192 Japan \\ E-mail: miyano@med.miyazaki-u.ac.jp
}

\begin{abstract}
University students evaluated a computer role playing game as a self-help tool of cognitive behavior therapy for the prevention of depression. Survey responses and text mining approach revealed that this computer role playing game was preferable to a workbook, a website program, and a board game as a selfhelp tool and was evaluated as "amusing," "fun," and "preferable." Results suggest that according to subject preferences computer role playing games can be an acceptable self-help tool for preventing depression for university students.
\end{abstract}

Keywords Depression, Cognitive Behavior Therapy, Self-help, Computer game, Text mining 